\title{
Universiteit
}

Leiden

The Netherlands

\section{Opmerkingen bij de voorgenomen herziening van het stelsel geweldsaanwending politieambtenaren}

Voorde, J.M. ten

\section{Citation}

Voorde, J. M. ten. (2016). Opmerkingen bij de voorgenomen

herziening van het stelsel geweldsaanwending politieambtenaren.

Proces: Tijdschrift Voor Strafrechtspleging, 95(1), 40-54.

doi:10.5553/PROCES/016500762016095001005

Version: $\quad$ Publisher's Version

License: $\quad$ Leiden University Non-exclusive license

Downloaded from: $\quad$ https://hdl.handle.net/1887/43394

Note: To cite this publication please use the final published version (if applicable). 


\title{
Opmerkingen bij de voorgenomen herziening van het stelsel geweldsaanwending politieambtenaren*
}

\author{
Jeroen ten Voorde
}

\section{Inleiding}

Binnen de Nationale Politie bestaat al enige tijd het verlangen de bestaande regelgeving met betrekking tot de geweldsaanwending van politieambtenaren te herzien. Korpschef Bouman wist de toenmalige minister van Veiligheid en Justitie, Opstelten, te bewegen tot een integrale herziening van de wet- en regelgeving en procedures rondom de geweldsaanwending door politieambtenaren.

De herziening lijkt te zijn ingegeven door een aantal geruchtmakende incidenten waarbij politieambtenaren geweld (vaak vuurwapengeweld) aanwendden in de uitoefening van hun functie. Deze incidenten hebben er in een aantal gevallen toe geleid dat, al dan niet na een procedure volgens artikel 12 van het Wetboek van Strafvordering (Sv), een politieambtenaar werd vervolgd voor het neerschieten van (of het op andere wijze gebruikmaken van geweld tegen) een verdachte persoon. De vervolging van politieambtenaren leidde vaak tot onrust binnen de politieorganisatie. Die onrust werd deze zomer naar buiten geventileerd door de hiervoor al genoemde Bouman naar aanleiding van een vonnis van de Rechtbank Limburg waarin een politieambtenaar wegens poging tot doodslag tot twee jaar onvoorwaardelijke gevangenisstraf werd veroordeeld. ${ }^{1}$ De omstandigheid dat hij, ten tijde van het feit lid van een arrestatie-eenheid, in de uitoefening van zijn functie handelde, vormde volgens de rechtbank 'onvoldoende valide reden' om hem geen onvoorwaardelijke gevangenisstraf op te leggen.

Het doel van de stelselherziening is om de rechtspositie van de politieambtenaar die geweld aanwendt te verduidelijken en, vanuit het oogpunt van de politie, te verbeteren. Daarmee wordt zowel de materiële als de formele positie bedoeld. Er wordt overwogen om de positie van politieambtenaren anders te regelen, waarbij meer recht zou worden gedaan aan de bijzondere omstandigheden waaronder politieambtenaren hun taak uitoefenen en daarbij geweld mogen aanwenden. Daarbij is vooral de vraag of een politieambtenaar die geweld heeft aangewend als verdachte of, zoals nu in de regel het geval is, als getuige wordt aangemerkt. De plannen zijn nog niet in detail bekend. In een artikel in het tijdschrift Blauw en in

* Prof. mr. dr. Jeroen ten Voorde is universitair hoofddocent Straf(proces)recht aan de Universiteit Leiden en bijzonder hoogleraar Strafrechtsfilosofie (leerstoel Leo Polak) aan de Rijksuniversiteit Groningen, en tevens redactielid van PROCES. De auteur is lid van de klankbordgroep stelselherziening geweldsaanwending politieambtenaren. Deze bijdrage is op persoonlijke titel geschreven.

1 Rb. Limburg 17 juli 2015, Nieuwsbrief Strafrecht 2015/202, m.nt. J.A.A.C. Claessen. 
een brief aan de Tweede Kamer wordt een beeld van de plannen geschetst. ${ }^{2}$ In deze bijdrage worden enkele opmerkingen bij de voorgestelde plannen geplaatst.

\section{Knelpunten in de huidige regelgeving}

\section{Het materiële recht}

Alvorens de voorgestelde wijzigingen te bespreken wil ik kort enkele knelpunten bespreken. Om dat te kunnen doen wordt eerst het bestaande wettelijk kader in penseelstreken beschreven. ${ }^{3}$

Artikel 7 Politiewet 2012 bepaalt dat politieambtenaren die zijn aangesteld voor de uitvoering van de in artikel 3 Politiewet 2012 omschreven politietaak, in de rechtmatige uitoefening van hun bediening bevoegd zijn geweld aan te wenden. Daaraan wordt in het eerste lid direct de beperking toegevoegd dat enkel het met het aanwenden van geweld beoogde doel, 'mede gelet op de aan het gebruik hiervan verbonden gevaren' dit geweld rechtvaardigt terwijl 'dat doel niet op een andere wijze kan worden bereikt.' In het vijfde lid van artikel 7 wordt bepaald dat de uitoefening van bevoegdheden (waarmee ook het geweld wordt bedoeld) 'in verhouding tot het beoogde doel redelijk en gematigd [dient] te zijn'. Doelbinding en proportionaliteit en subsidiariteit zijn bij de geweldsbevoegdheid sleutelbegrippen. Naeyé wijst erop dat uit artikel 7 een 'aanvalsplicht' kan worden afgeleid. Als bij het bereiken van een bepaald doel geweld moet worden gebruikt, moet dat niet worden geschuwd. ${ }^{4}$ Ik leid een dergelijke plicht niet uit de wet af. In artikel 7 lid 1 wordt gesproken van een bevoegdheid geweld te gebruiken. Die bevoegdheid maakt het mogelijk geweld aan te wenden, terwijl die bevoegdheid een vooronderstelling van rechtmatigheid van het aangewende geweld oplevert. De plicht ziet op het vervullen van de taak binnen de grenzen die het recht stelt. Als men de praktijk van de taakuitoefening als een aanval zou willen beschouwen, dan meen ik dat die aanval op allerlei manieren kan geschieden. Het aanwenden van geweld is voor de taakuitoefening volgens mij niet zonder meer nodig en niet altijd gewenst.

De regels voor het aanwenden van geweld staan niet in de Politiewet 2012, maar in de in artikel 9 van die wet genoemde Ambtsinstructie voor de politie en de Koninklijke Marechaussee en andere opsporingsambtenaren (hierna: Ambtsinstructie). De huidige versie dateert van 1994 en is sindsdien meermalen gewijzigd (voor het laatst in 2012). ${ }^{5}$ In de Ambtsinstructie wordt bepaald wat (het aanwenden van) geweld inhoudt (art. 1 lid 3). Van belang is ook het bepaalde in artikel 4 van de Ambtsinstructie, waarin staat dat het geweld slechts mag worden aange-

2 Herziening stelsel geweldsaanwending, Blauw 2015, 8, p. 8-12 (hierna: Blauw 2015); Kamerstukken II 2015/16, 29628, 588.

3 Zie J.M. ten Voorde, 'Politieel vuurwapengebruik in rechte beoordeeld', Ars Aequi 2014, p. 346-352.

4 J. Naeyé, 'De geweldsbevoegdheid', in: J. Naeyé (red.), Hard én zacht: geweld in publiekscontacten van de politieregio Amsterdam-Amstelland, Amsterdam: Centrum voor Politiewetenschappen Vrije Universiteit Amsterdam, p. 35-44.

5 Stb. 1994, 275. 
wend door een politieambtenaar aan wie het geweldsmiddel rechtens is toegekend voor zover hij optreedt ter uitvoering van de taak met het oog waarop het geweldsmiddel aan hem is toegekend. Op die manier wordt duidelijk gemaakt dat het zijn van politieambtenaar niet automatisch betekent dat deze geweld mag aanwenden. Die bevoegdheid moet hem zijn toegekend. Ook is van belang dat het aanwenden van geweld altijd verband houdt met de uitvoering van de taak die aan de politieambtenaar is toegekend. Geen geweld zonder doel, geen doel zonder dat dit met het uitvoeren van een opgedragen taak verband houdt. In artikel 4 staat ook dat de politieambtenaar slechts het geweldsmiddel mag aanwenden wanneer hij in het gebruik daarvan is geoefend. Er bestaan ook regels voor bewapening en uitrusting en beheer over wapens en munitie. ${ }^{6}$

In de Ambtsinstructie zijn ook vormen van geweld (gebruik van vuurwapens, surveillancehond en pepperspray) omschreven. Daarin komt een eerste knelpunt van de Ambtsinstructie naar voren. ${ }^{7}$ Niet alle vormen van geweld zijn daarin omschreven. De nekklem, waarover zoveel te doen is geweest in de zaak van de dood van Mitch Henriquez, is bijvoorbeeld niet in de Ambtsinstructie opgenomen. Dat lijkt een leemte. We kunnen ons afvragen of de Ambtsinstructie een uitputtende omschrijving van de door de politie aan te wenden vormen van geweld moet geven. Dat lijkt voor de hand te liggen. ${ }^{8}$ De overheid die tegen burgers geweld aanwendt, mag dat in een democratische rechtsstaat, die mede onze vrijheden dient te beschermen, slechts spaarzaam doen. Artikel 4 van de Ambtsinstructie kan als een uitwerking van dat uitgangspunt worden beschouwd. Immers, het bepaalt dat een bevoegdheid moet worden toegekend en dat lijkt slechts mogelijk wanneer die bevoegdheid ergens is omschreven. Ook de in artikel 4 genoemde eis van geoefendheid in het gebruik lijkt een regeling van het geweldsmiddel te veronderstellen. Belangrijker is dat voor het beoordelen van de vraag of geweld mag worden aangewend en, zo ja, welk geweld, de eisen van proportionaliteit en subsidiariteit in acht moeten worden genomen. Zonder duidelijke regeling van een geweldsmiddel krijgt die beoordeling een ad-hoc- en daarmee mogelijk willekeurig karakter. Dat komt de rechtmatigheid en legitimiteit van het optreden niet ten goede. De discussie naar aanleiding van de zaak-Henriquez maakt dit duidelijk.

Het geweld dat een politieambtenaar aanwendt, kan ernstige gevolgen hebben voor de persoon (of de goederen) tegen wie het geweld wordt aangewend. De meeste aandacht krijgen zaken met dodelijke afloop. Naar de letter van de wet worden met deze feiten de bestanddelen van een delictsomschrijving vervuld. De strafwet pleegt het rechtmatig optreden van politieambtenaren buiten de delictsomschrijving te houden door toevoeging van het bestanddeel 'wederrechtelijk' (vandaar dat bij een rechtmatige aanhouding niet de delictsomschrijving van art.

6 Zie bijv. Besluit bewapening en uitrusting politie van 13 oktober 2012, Stb. 2012, 511; Regeling beheer wapens en munitie politie 2015, Stcrt. 2015, 17308; Regeling toetsing geweldsbeheersing politie, Stcrt. 2001, 247. Een nieuwe regeling toetsing geweldsbeheersing politie wordt per 1 januari 2016 verwacht.

7 Vgl. Y.M. van der Vlugt e.a., Verantwoord politiegeweld, rapport Nationale ombudsman 2013/055.

8 Of het ook mogelijk is, is de vraag. Technologische en andere ontwikkelingen kunnen telkens om aanpassing van de Ambtsinstructie vragen, tenzij wordt geopteerd voor een techniek-neutrale regeling. 
282 van het Wetboek van Strafrecht (Sr) wordt vervuld) of het bestanddeel 'met overschrijding van zijn bevoegdheid' (art. 370 en 371 Sr) en 'zonder inachtneming van de bij de wet bepaalde vormen' (art. $370 \mathrm{Sr}$ ). Om die reden heeft een politieambtenaar die rechtmatig geweld aanwendt waarbij een ander opzettelijk pijn en letsel wordt toegebracht, niet mishandeld, omdat voor zijn handelen een rechtvaardigingsgrond bestaat. ${ }^{9} \mathrm{Bij}$ doodslag en zware mishandeling ontbreekt wederrechtelijkheid als bestanddeel, zodat een politieambtenaar die een ander met opzet van het leven berooft of zwaar lichamelijk letsel toebrengt, naar de letter van de wet de delictsomschrijving van doodslag of zware mishandeling vervult. ${ }^{10}$ Voor een politieambtenaar die handelt in overeenstemming met de regels, kan het vreemd voorkomen dat ook hij de bestanddelen van een delictsomschrijving heeft vervuld. In het artikel in Blauw wordt aangegeven dat het er in deze gevallen op lijkt dat het handelen van politieambtenaren wordt gecriminaliseerd. Dat zou niet deugen. ${ }^{11}$ Een wetswijziging zou voor deze gevallen daarom gewenst zijn. Tegelijkertijd kan men zich afvragen waarom de wetgever heeft gemeend dat wederrechtelijkheid geen bestanddeel is bij moord en doodslag en zware mishandeling. Is dat wellicht omdat, ook wanneer iemand handelt in de rechtmatige uitoefening van zijn functie, hij een ander in beginsel niet dient te doden? Heeft de wetgever niet willen inscherpen dat het recht op leven (en op lichamelijke integriteit) zo belangrijk is dat ook overheidsdienaren die geweld mogen aanwenden, ter verantwoording mogen worden geroepen voor het daadwerkelijk aanwenden van dat geweld met dodelijke afloop of ernstig letsel tot gevolg?

Een wetswijziging wordt ook bepleit met betrekking tot de strafbaarheid van de politieambtenaar. ${ }^{12}$ Ingeval het feit bewezen wordt verklaard en strafbaar is, is de volgende vraag in het strafvorderlijk beslissingsmodel (art. 348/350 Sv) of de verdachte strafbaar is. Niet strafbaar is hij die met succes een beroep kan doen op een strafuitsluitingsgrond. In de huidige situatie kan een politieambtenaar die conform de Ambtsinstructie heeft gehandeld, een beroep doen op de rechtvaardigingsgrond wettelijk voorschrift (art. $42 \mathrm{Sr}$ ). Een succesvol beroep op een rechtvaardigingsgrond betekent dat het feit niet strafbaar is. Met andere woorden: wat de verdachte deed, is gerechtvaardigd. Wanneer de politieambtenaar niet conform de Ambtsinstructie heeft gehandeld, komt hem een beroep op alle andere

9 Vgl. HR 5 juli 2011, NJ 2011/466, m.nt. N. Keijzer. Dit geldt ook voor de strafverzwarende omstandigheden in art. $300 \mathrm{Sr}$ (zwaar lichamelijk letsel (lid 2) en de dood (lid 3)).

10 Mogelijk levert de kwalificatie doodslag en zware mishandeling ruimte op voor differentiatie tussen door burgers en door politieambtenaren aangewend geweld. De Hoge Raad gebruikt kwalificaties tegenwoordig vaker om strafbaarstellingen af te bakenen. Zie bijv. bij witwassen (HR 7 december 2013, NJ 2014/75, m.nt. M.J. Borgers).

11 Blauw 2015, p. 9-10.

12 Bij Defensie heeft enige jaren geleden een vergelijkbare discussie gespeeld en is er onder meer voor gekozen in het Wetboek van Militair Strafrecht een strafuitsluitingsgrond op te nemen voor de gevallen waarin tijdens een missie conform de regels geweld wordt gebruikt. Doel van deze wetswijziging was 'de legitimatie van geweldgebruik door militairen op een meer eenduidige wijze in de wet' vast te leggen, aldus G.L. Coolen (Militair strafrecht (bewerkt door G.F. Walgemoed en J.J.M. van Hoek), Deventer: Kluwer 2013, p. 47). Zie kritisch over de nieuwe regeling P.A. Kingma, 'De herziening van de artikelen 38 en 71 Wetboek militair strafrecht: symbool of noodzaak?', Militair Rechtelijk Tijdschrift 2011, p. 207-220 (i.h.b. p. 216-219). 
(wettelijke en buitenwettelijke) strafuitsluitingsgronden toe. In het oog springen daarbij noodweer ${ }^{13}$ en noodweerexces, overmacht in de zin van noodtoestand, psychische overmacht ${ }^{14}$ en een bijzondere vorm van afwezigheid van alle schuld, namelijk putatief noodweer. ${ }^{15}$ Bij putatief noodweer (de politieambtenaar heeft zich verschoonbaar vergist in de noodweersituatie) is er geen sprake van een rechtvaardigingsgrond, maar ontbreekt de persoonlijke schuld. De politieambtenaar kon niet vermijden anders te handelen en de delictsomschrijving vervullen. Bij de beoordeling van een beroep op deze strafuitsluitingsgronden kan rekening worden gehouden met de bijzondere positie die de politieambtenaar ten tijde van het plegen van de feiten vervulde. Deze zogeheten Garantenstellung biedt ruimte om bijvoorbeeld bij noodweer een op de functie van de verdachte toegespitst oordeel te vellen en daardoor minder rekening te houden met het subsidiariteitsvereiste. ${ }^{16}$ Deze Garantenstellung houdt niet in dat politieambtenaren altijd vrijuit zullen gaan als zij (in strijd met de Ambtsinstructie) geweld aanwenden in de uitoefening van hun functie, wel betekent zij dat bij de beoordeling van het handelen en de persoon van de verdachte rekening wordt gehouden met de omstandigheden die verband houden met de bijzondere positie die politiefunctionarissen in het rechtsbestel innemen. ${ }^{17}$

Juist de omstandigheid dat de Garantenstellung geen garantie biedt dat een politieambtenaar die geweld aanwendt vrijuit gaat, kan door hem als nadelig worden ervaren. Het gevoel kan ontstaan dat in een concreet geval geen rekening wordt gehouden met de bijzondere positie van politieambtenaren die 'the thin blue line' vormen en om die reden betere rechtsbescherming dan 'gewone' burgers zouden verdienen. De bijzondere positie vergt een bijzondere, dat wil zeggen uitsluitend voor politieambtenaren toe te passen, regelgeving waarin die Garantenstellung als uitgangspunt wordt genomen, niet als 'regulerend beginsel'18 dat bij de beoordeling van een strafuitsluitingsgrond kan worden betrokken. Tegelijkertijd wijst de omstandigheid dat de wet in het geval van moord en doodslag en zware mishandeling geen wettelijke uitzondering voor bepaalde personen met bijzondere bij wet geregelde bevoegdheden kent, erop dat de bijzondere positie voor politieambtenaren voor hen geen uitzonderingssituatie mag opleveren. Politieambtenaren handhaven het recht, zij staan er in het vervullen van die taak niet boven. ${ }^{19}$

13 In het artikel in Blauw per abuis een schulduitsluitingsgrond genoemd (p. 9).

14 Zie echter HR 17 november 1987, NJ 1988/809, m.nt. G.E.M.

15 Zie J.S. Timmer, Politiegeweld: geweldgebruik van en tegen de politie in Nederland (dissertatie Vrije Universiteit Amsterdam), Alphen aan den Rijn: Kluwer 2005, p. 202-208.

16 Zie J.M. ten Voorde, 'De Garantenstellung van politieambtenaren bij vuurwapengebruik en de aanname van noodweer', Delikt en Delinkwent 2008, p. 781-802.

17 Vgl. HR 26 mei 2015, NJ 2015/271.

18 Zie voor deze terminologie J. de Hullu, Materieel strafrecht: over de grenzen van strafrechtelijke aansprakelijkheid naar Nederlands recht, Deventer: Kluwer 2015, hoofdstuk V (passim).

19 Vgl. J.A.A.C. Claessen in zijn annotatie onder Rb. Limburg 17 juli 2015, Nieuwsbrief Strafrecht 2015/202. 


\section{Het formele recht}

Wanneer sprake is van (dodelijk vuurwapen)geweld, treedt een bepaalde procedure in werking. ${ }^{20}$ In de Ambtsinstructie wordt aangegeven dat elk geweld door de politieambtenaar wordt gemeld (art. 17). Ook in geval van dodelijk vuurwapengeweld wordt onderzoek gedaan naar de toedracht van dat geweld. Dat onderzoek wordt uitgevoerd door de Rijksrecherche. De inzet van de Rijksrecherche wordt bepaald door de Aanwijzing taken en inzet Rijksrecherche. ${ }^{21}$ De procedure is dat de politieambtenaar die geweld heeft aangewend in beginsel binnen 24 uur wordt gehoord als getuige. Voorafgaand aan dit gesprek wordt hem medegedeeld geen antwoord te hoeven geven op vragen 'indien hij [zich] door beantwoording daarvan aan het gevaar van een vervolging kan blootstellen'. Het onderzoek moet erop gericht zijn de officier van justitie in staat te stellen antwoord te geven op de vragen van het beslissingsmodel van artikel 348/350 Sv. Als uitgangspunt geldt dat 'van strafvervolging (...) wordt afgezien indien geen rechtens relevante twijfel kan bestaan over het bevestigende antwoord op de vraag of de strafrechter, indien de zaak aan hem zou zijn voorgelegd, een beroep op een rechtvaardigings- of schulduitsluitingsgrond zal honoreren en de politiefunctionaris zal ontslaan van [alle] rechtsvervolging, ${ }^{22}$ Alvorens te kunnen beslissen of tot vervolging van de politieambtenaar wordt overgegaan, dient een zaak voor advies aan de Adviescommissie politieel vuurwapengebruik te worden voorgelegd. Haar advies is voor die beslissing van (groot) belang. ${ }^{23}$

Welke positie de opsporingsambtenaar inneemt, verdachte of getuige, is al langere tijd een punt van discussie binnen de politie. De rechtspositionele voordelen van het zijn van verdachte (bijvoorbeeld het recht op rechtsbijstand, het zwijgrecht (meer algemeen het nemo-teneturbeginsel), het recht tot toegang tot processtukken, het recht om einde zaak te verzoeken en dergelijke) spreken velen inmiddels aan. Tegelijkertijd wordt het zijn van verdachte beschouwd als criminalisering van politieambtenaren die geweld hebben aangewend. ${ }^{24}$ Voor een politieambtenaar is de procedure naar aanleiding van het aanwenden van (vuurwapen)geweld indringend. We mogen aannemen dat de tijd waarin hij (of zij) voorwerp is van onderzoek, hem niet licht zal vallen. Het belang van zorgvuldigheid staat echter voorop en is ook een belangrijke eis van het Europees Hof voor de Rechten van de Mens (EHRM). Dat Hof tikte Nederland in 2007 op de vingers vanwege een onzorgvuldig uitgevoerd onderzoek naar aanleiding van een dodelijk

20 Onderzoek naar het gebruik van geweld door de politie ontbeert een eenduidige regeling (zie het in voetnoot 7 genoemde rapport van de Nationale ombudsman). De minister van Veiligheid en Justitie heeft aangekondigd hierin verandering aan te brengen. Zie Kamerstukken II 2015/16, 29628, 588, p. 2.

21 Aanwijzing van 13 december 2010, Stcrt. 2010, 20477.

22 Hieruit wordt de gelijkschakeling tussen politieambtenaren en burgers in geval van dodelijk geweld opnieuw zichtbaar. Ook een politieambtenaar kan de bestanddelen van doodslag (art. 287 Sr) vervullen, maar komt een beroep op een strafuitsluitingsgrond toe, ook wanneer hij in strijd met de Ambtsinstructie heeft gehandeld.

23 Zie Aanwijzing afloopberichten aan de verantwoordelijke van 11 februari 2008, Stcrt. 2008, 45.

24 Blauw 2015, p. 10. 
schietincident. ${ }^{25}$ Het vormgeven van een nieuwe procedure zal dan ook niet strijdig mogen zijn met de kaders die het EHRM in zijn rechtspraak heeft neergelegd. Dat die rechtspraak mogelijk wat streng overkomt, maakt andermaal duidelijk dat overheidsgeweld geen onvermijdelijk gevolg mag zijn van het geweldsmonopolie. Overheidsgeweld moet in een democratische rechtsstaat een punt van grote zorg en aandacht zijn. In communicatie richting overheidsfunctionarissen die geweld mogen aanwenden, zoals politieambtenaren, moet die boodschap bij herhaling worden verteld en onderdeel zijn van het zelflerend/zelfreflecterend vermogen van de (politie)organisatie.

\section{Wijzigingen (1): het materiële recht}

\section{Een nieuwe strafbaarstelling: schending van de Ambtsinstructie}

Twee wijzigingen in het materiële recht, die naast een actualisering van de Ambtsinstructie worden voorgesteld, verdienen bespreking. Het betreft de introductie van een nieuwe strafbaarstelling (overtreding van de geweldsinstructie) en van een nieuwe strafuitsluitingsgrond. De introductie van de nieuwe strafuitsluitingsgrond wordt door de minister als volgt gerechtvaardigd: 'Wanneer een opsporingsambtenaar als gevolg van een geweldsaanwending wordt vervolgd voor commune delicten als mishandeling en doodslag, komt de bijzondere positie van de opsporingsambtenaar onvoldoende tot zijn recht. De opsporingsambtenaar die gebruik heeft gemaakt van zijn geweldsbevoegdheid is namelijk niet vergelijkbaar met personen die geen geweldsbevoegdheid hebben. Het huidige Wetboek van Strafrecht kent voor de vervolging van opsporingsambtenaren echter geen andere strafbaarstelling dan de commune geweldsdelicten.' ${ }^{26}$ In het artikel in Blauw wordt de strafbepaling schending van de Ambtsinstructie genoemd. ${ }^{27}$ Daarin wordt opgemerkt dat er een verschil bestaat 'of het een politieambtenaar is die in het kader van zijn werk optrad, of dat het om een burger gaat die willens en wetens geweld heeft gebruikt. Daar zit een enorm spanningsveld (...).' En: 'In die gevallen dat het verkeerd gaat, moeten we kijken wat gepast is voor die politieambtenaar. Laat de straf dan passen bij de uitoefening van het vak. Zoek het in andere werkzaamheden, het ontnemen van een executieve status of verplichte trainingen op het thema. ${ }^{28}$

\section{Enkele opmerkingen bij het voorgenomen wetsvoorstel}

Het voorstel voor de nieuwe strafbaarstelling wekt bij mij de indruk dat het geweld als zodanig niet meer het onderzoeken waard is, maar de vraag moet worden beperkt of de politieambtenaar zich aan zijn eigen regels heeft gehouden. Zo wordt onderzoek naar geweld tegen een burger een aangelegenheid waarbij het werkelijke onderwerp (de gedode burger) niet mag worden besproken. Niet het 
geweld staat ter discussie, maar het al dan niet naleven van regels. De vraag of de regels zijn nageleefd, is van belang, maar belangrijker is volgens mij de vraag wat er precies is gebeurd. Wie heeft welk geweld tegen wie en waarom aangewend? Was dat geweld volgens de regels? Zo ja, waarom, en zo nee, was het uit anderen hoofde gerechtvaardigd? Het zijn deze vragen die volgens de rechtspraak van het EHRM gesteld en beantwoord moeten worden. ${ }^{29}$ Daaruit volgt geen verplichting tot veroordeling van politieambtenaren wegens (poging tot) moord of doodslag. Wel moet worden voorkomen dat dergelijke gedragingen in de regel onbestraft blijven. ${ }^{30}$

Volgens het EHRM is politiegeweld geweld. We mogen weliswaar aannemen dat politieambtenaren die geweld aanwenden dat in de regel doen wanneer zij hun taak uitoefenen, maar het blijft geweld. Dodelijk geweld is in beginsel in strijd met artikel 2 van het Europees Verdrag voor de rechten van de mens (EVRM). De verdragsstaten moeten er daarom alles aan doen om te voorkomen dat door politieambtenaren dodelijk geweld wordt uitgeoefend. De rechtvaardigingen voor dodelijk geweld, genoemd in het tweede lid van artikel 2, zijn slechts bij hoge uitzondering toelaatbaar. ${ }^{31}$ Het is vanuit dit perspectief dat wetgevende maatregelen die verband houden met de regulering van dodelijk politieel geweld, moeten worden beschouwd. Dat de minister van Veiligheid en Justitie beoogt de wettelijke regeling zo vorm te geven dat niet het dodelijk geweld maar het al dan niet schenden van de Ambtsinstructie centraal komt te staan, lijkt mij niet zonder meer verenigbaar met het EVRM. Dat betekent niet dat de strafbaarstelling op zichzelf ontoelaatbaar is. Het gaat erom dat de indruk ontstaat dat niet het geweld, maar het al of niet naleven van regels centraal komt te staan. De minister geeft toe dat het Openbaar Ministerie ook het geweld centraal kan stellen. Het opportuniteitsbeginsel biedt het Openbaar Ministerie een zekere keuzevrijheid voor welk(e) feit(en) het kan vervolgen. Dat neemt de indruk dat het geweld niet centraal hoeft te staan niet helemaal weg, terwijl uit de rechtspraak van het EHRM valt af te leiden dat die wel moet worden weggenomen.

Van belang is dat ook wordt geadresseerd wat wordt bedoeld met het verschil tussen politieambtenaren en gewone burgers. Dat verschil maakt de wetgever op het niveau van moord en doodslag niet. We zagen dat hieruit zou kunnen volgen dat de wetgever kennelijk meent dat er geen verschil mag bestaan tussen politieambtenaren en gewone burgers. ${ }^{32}$ De door deze bepalingen beschermende fundamentele rechten maken dat alle daders van deze feiten in beginsel gelijk zijn. Onderscheid wordt pas gemaakt op het niveau van de strafbaarheid, niet op het niveau van het delict zelf. Wanneer de minister (met de politie) van mening is dat er ook op het niveau van het delict een verschil bestaat tussen gewone burgers en poli-

29 Zie o.a. EHRM 5 november 2009, nr. 1108/02 (Kolevi/Bulgarije).

30 Zie o.a. EHRM 12 februari 2004, nr. 47287/99 (Perez/Frankrijk); EHRM 24 maart 2009, nr. 11818/02 (Mojsiejew/Polen).

31 Zie o.a. EHRM 24 maart 2011, nr. 23458/02 (Guiliani en Gaggio/Italië).

32 Het EHRM hecht bijzonder veel belang aan onderzoek naar de dood van burgers als gevolg van overheidsgeweld. Zie o.a. EHRM 13 juni 2002, nr. 38361/97 (Anguelova/Bulgarije). Daaruit zou eventueel kunnen worden afgeleid dat het Hof het verschil tussen politieambtenaren en gewone burgers niet erkent. 
tieambtenaren, moet de discussie op dat niveau worden gevoerd. Door dat evenwel na te laten blijft de politieambtenaar die dodelijk geweld aanwendt volgens de strafwet gelijk aan de gewone burger. Op die manier creëert de nieuwe strafbaarstelling slechts ogenschijnlijk een bijzondere positie voor de politie. In de praktijk hoeft er niet veel te veranderen. Dat beeld wordt versterkt doordat valt te verwachten dat de beslissing om te vervolgen voor een ander feit dan (poging tot) moord of doodslag of zware mishandeling via een artikel $12 \mathrm{~Sv}$-procedure bij het gerechtshof zal worden aangevochten door slachtoffers of nabestaanden, met het verzoek voor een ander feit te vervolgen. ${ }^{33}$ Gelet op de maatschappelijke impact van dergelijke zaken is niet ondenkbaar dat het EHRM (ook) de vervolging voor die feiten beveelt. Een nieuwe strafbaarstelling vormt al met al geen garantie dat politieambtenaren nooit meer voor een zwaarder feit dan de voorgenomen strafbaarstelling zullen worden vervolgd. De kans bestaat zelfs dat politieambtenaren voor beide feiten worden vervolgd en berecht. Het laat zich raden hoe dat op hen zal overkomen.

De strafbaarstelling zelf roept ook vragen op. Is het niet naleven van wettelijke voorschriften op zichzelf zo ernstig dat dergelijk nalaten strafbaar moet worden gesteld? Die vraag zal in de memorie van toelichting moeten worden beantwoord. Nalaten kan strafbaar worden gesteld omdat de verplichting een norm na te leven zo belangrijk is dat het nalaten daarvan volstrekt onaanvaardbaar is, terwijl de dader de mogelijkheid en capaciteit had het nalaten te voorkomen. ${ }^{34}$ Welke normen zijn zo belangrijk dat het nalaten die norm na te leven strafbaar moet worden gesteld? Het ligt voor de hand dat dit in ieder geval normen zijn die verband houden met de bescherming van fundamentele rechtsgoederen, zoals lijf en leven. ${ }^{35}$ Het niet naleven van normen is strafbaar, niet alleen omdat daardoor deze rechtsgoederen zijn gekrenkt (of: schade aan anderen is toegebracht), maar ook omdat daardoor deze rechtsgoederen kunnen worden gekrenkt (of: gevaar voor schade kan worden veroorzaakt). Het gevaar dat door het niet naleven van bepaalde normen in het leven wordt geroepen, rechtvaardigt strafbaarstelling. Dat betekent wel dat de strafbaarstelling niet enkel verband houdt met de in het geding zijnde normen. Het gaat ook om het gevaar of risico dat met schending van die normen fundamentele rechtsgoederen kunnen worden gekrenkt. Die rechtsgoederen, zoals het leven, zijn ook bij een strafbaarstelling van het niet

34 Zie over het strafbaar stellen van nalaten o.a. A. Ashworth, Positive obligations in criminal law, Oxford/Portland, Oregon: Hart Publishing 2015, hoofdstuk 2.

35 Vgl. EHRM 27 september 1995, Series A no. 324 (McCann and Others/Verenigd Koninkrijk); EHRM 28 september 2015, nr. 23380/09 (Bouyid/België). 
naleven van normen (op de achtergrond) in het geding. ${ }^{36}$ Verboden wapenbezit is mede strafbaar omdat met wapens het leven van mensen kan worden benomen. Bij daadwerkelijke schending van die rechtsgoederen is de vraag of het zo vanzelfsprekend is dat die rechtsgoederen op de achtergrond blijven staan. Dat is denkbaar. De verdachte van doodslag met een vuurwapen waarbij het vermoeden bestaat dat hij in noodweer heeft gehandeld, hoeft natuurlijk niet voor doodslag te worden vervolgd. Vervolging voor verboden wapenbezit blijft wel mogelijk. De dodingshandeling hoeft geen onderdeel te zijn van discussie tijdens het onderzoek ter terechtzitting. In hoeverre dat helemaal te vermijden valt, is natuurlijk de vraag. Uit de rechtspraak van het EHRM blijkt dat in geval van dodelijk geweld (door overheidsdienaren) door de overheid effectief onderzoek moet worden verricht. Tijdens dat onderzoek moet, zo leid ik uit de rechtspraak van het Hof af, geen delict bij voorbaat worden uitgesloten.

Bij strafbaarstelling van het nalaten normen na te leven kan ook de positie van de dader een argument zijn dit nalaten strafbaar te stellen. Juist omdat van bepaalde personen wordt verwacht dat zij zich aan de hun voorgeschreven normen houden, ligt strafbaarstelling in de rede wanneer zij zich daaraan niet hebben gehouden. Dat plaatst de persoon die deze norm kan overtreden onder het vergrootglas. In veel beroepsgroepen is overtreding van bepaalde normen niet zonder meer strafbaar in het commune strafrecht. Overtreding van normen wordt vaak disciplinair afgedaan en valt onder omstandigheden, wanneer een bepaald ernstig gevolg is ingetreden, onder de strafwet (denk aan dood door schuld bij een foutief verlopen operatie). In casu wordt besloten (alle?) handelingen die in strijd zijn met de gewelds- of Ambtsinstructie onder het bereik van de strafwet te plaatsen. Kennelijk is naleving van de Ambtsinstructie zo belangrijk, dat schending niet (alleen) tot disciplinaire maatregelen kan leiden, ${ }^{37}$ maar zelfs tot strafvervolging en het opleggen van straf. Hoewel dit feit iets anders is dan doodslag en het strafmaximum niet hetzelfde zal zijn, is het een strafbaar feit, waarvoor bestraffing mogelijk is.

Hoe nadrukkelijk die achterliggende rechtsgoederen in het geding zijn, bepaalt de vormgeving van de delictsomschrijving. Twee varianten zijn denkbaar: (1) De politieambtenaar, marechaussee of buitengewoon opsporingsambtenaar die opzettelijk de Ambtsinstructie (enz.) niet naleeft, wordt gestraft met (...), en (2) De politieambtenaar (enz.) die opzettelijk geweld aanwendt tegen een ander, wetende dat hij daarbij de Ambtsinstructie (enz.) niet naleeft, wordt gestraft met (...). In het eerste geval zijn de rechtsgoederen geen onderdeel van de delictsomschrijving en dus slechts op de achtergrond aanwezig, in het tweede geval zijn de rechtsgoederen onderdeel van de delictsomschrijving en moet het geweld worden bewezen. Het lijkt erop dat de minister kiest voor de eerste variant, omdat hij wil voorkomen dat de politieambtenaar voor het plegen van geweld terechtstaat. Om de omvang van de delictsomschrijving niet te groot te maken ligt het in dat geval voor de hand dat naast een opzetvereiste ook duidelijk is welke overtreding van de Ambtsinstructie precies strafbaar is. In de tweede variant hoeft dat laatste wat minder goed duidelijk te worden gemaakt, omdat het geweld onderdeel is van de delictsomschrijving. In die tweede variant wordt het geweld betrokken bij de beoordeling van de feiten. Een voordeel daarvan zou wellicht kunnen zijn dat in meer gevallen een art. $12 \mathrm{~Sv}$-procedure wordt voorkomen. Dit zal naar ik vermoed echter wel mede afhangen van het strafmaximum waarvoor de wetgever kiest.

37 Zie Ten Voorde 2014. 
De voorgestelde strafbaarstelling scherpt de Garantenstellung van politieambtenaren aan; zij plaatst haar namelijk nog verder onder het bereik van de strafwet. ${ }^{38}$ Dat maakt politieambtenaren inderdaad anders dan gewone burgers, een belangrijk argument voor deze strafbaarstelling. Maar voor gewone burgers geldt niet zonder meer dat als zij bepaalde normen op het werk niet naleven, daarvoor door de strafrechter kunnen worden bestraft. ${ }^{39}$ Waarom politieambtenaren zo anders zijn dat zij wel kunnen worden gestraft, is (nog) niet duidelijk. Het argument dat de Ambtsinstructie betrekking heeft op de geweldsbevoegdheid, is nauwelijks bevredigend omdat het gaat om het overtreden van normen, niet om het gepleegde geweld. Het argument dat wordt voorkomen dat politieambtenaren voor iets zwaarders worden bestraft, zoals doodslag, kan misschien juist zijn, maar een politieambtenaar die wordt veroordeeld wegens overtreding van de Ambtsinstructie heeft een strafbaar feit begaan die in zijn justitiële documentatie komt te staan. Tenzij de wet op dit punt wordt aangepast (dat is nog de vraag), kan een veroordeling dus rechtspositionele consequenties hebben. Het verschil met doodslag is daarmee tot op zekere hoogte relatief. Daarbij geldt dat doodslag moet worden bewezen, terwijl een strafuitsluitingsgrond (met de Garantenstellung) hulp kan bieden om onder bestraffing uit te komen. Ik zie niet in hoe een strafuitsluitingsgrond hulp kan bieden bij een bewezenverklaring van schending van de Ambtsinstructie, tenzij men gebrek aan training als een strafuitsluitingsgrond zou willen introduceren, ${ }^{40}$ of het ambtelijk bevel (art. $43 \mathrm{Sr}$ ) zo wil oprekken dat alle handelingen van politieambtenaren per definitie het resultaat zijn van een bevel. Dan wordt niet alleen de strafbaarstelling een dode letter, op die manier wordt de politie min of meer een vrijbrief gegeven al datgene te doen wat zij wenselijk acht. Bij bewezenverklaring van schending van de Ambtsinstructie ligt straf dus in beginsel voor de hand. Een gevangenisstraf zal echter niet in de rede liggen, terwijl een taakstraf wellicht als denigrerend zal worden ervaren. Blijft over de geldboete (en het rechterlijk pardon). Is dat bevredigend? Ook voorwaardelijke straffen zijn mogelijk. In dat geval kan de rechter voorwaarden opleggen, het gedrag betreffende, zoals het volgen van cursussen op het gebied van het aanwenden van geweld. Die voorwaarden kunnen overigens ook worden opgelegd bij een veroordeling wegens doodslag of zware mishandeling. De toegevoegde waarde van de nieuwe strafbaarstelling is op dit punt gering. Op grond van artikel $28 \mathrm{Sr}$ kan de rechter de politieambtenaar uit bepaalde rechten ontzetten, mits de wetgever ertoe overgaat artikel $28 \mathrm{Sr}$ van toepassing te verklaren op het delict

De consequenties voor de beoordeling van andere strafuitsluitingsgronden laat ik hier in het midden. Niet ondenkbaar is dat het overtreden van de Ambtsinstructie als strafbaar feit in het nadeel van de politieambtenaar kan worden meegewogen bij de vraag of het beroep op een strafuitsluitingsgrond slaagt.

39 Ook overtredingen van wegenverkeersregels worden in de regel buiten het strafrecht om afgedaan.

40 Het gebrek aan training vormde een wezenlijk argument in de beoordeling van het beroep op noodweer in de zaak die leidde tot het bekende arrest Meta Hofman (HR 1 maart 1983, NJ 1983/468, m.nt. ThWvV). Zie hierover Th.J.B. Buiting, 'De affaire Meta Hofman', in: C. Kelk e.a. (red.), Grenzen en mogelijkheden: opstellen over en rondom de strafrechtspleging, Nijmegen: Ars Aequi Libri 1984, p. 140-152. 
schending van de Ambtsinstructie. De straf kan dan passen bij de uitoefening van het vak. Ontzetting uit het ambt is echter al buiten het strafrecht mogelijk. ${ }^{41} \mathrm{De}$ vraag is of de strafbaarstelling schending van de Ambtsinstructie met het oog op ontslag moet worden ingevoerd.

Zojuist had ik het over training. Mij lijkt dat een gevolg van de voorgenomen strafbaarstelling zal moeten zijn dat zo veel mogelijk wordt voorkomen dat politieambtenaren zich aan overtreding van deze bepaling schuldig zullen maken. Van een strafbaarstelling moet ook een preventieve werking uitgaan. Als gevolg daarvan zullen de opleidingen en permanente trainingen binnen de politie moeten worden geïntensiveerd, zullen de eisen waaraan een politieambtenaar moet voldoen om een vuurwapen te dragen nog strikter moeten worden gehandhaafd en de controle door leidinggevenden worden aangescherpt. Dit alles tenzij de politie vervolgingen wegens schending van de Ambtsinstructie voor lief neemt. Dat is niet voorstelbaar, want dat zou het beeld creëren van een organisatie die het niet zo nauw neemt met de op haar van toepassing zijnde normen. Voor een organisatie die tot taak heeft de daadwerkelijke handhaving van de rechtsorde, lijkt het mij dat dit beeld zo veel mogelijk moet worden voorkomen. De strafbaarstelling heeft tot gevolg dat bepaalde (tamelijk kostbare) zaken beter dan nu moeten worden geregeld. Het is de vraag of daarmee in het wetgevingstraject voldoende rekening wordt gehouden.

\section{Een nieuwe strafuitsluitingsgrond}

Naast de strafbaarstelling wordt ook een bijzondere strafuitsluitingsgrond in het Wetboek van Strafrecht geïntroduceerd die meer adequaat zou zijn toegesneden op de bijzondere positie van de opsporingsambtenaar. ${ }^{42}$ De minister: 'Ik werk (...) aan het formuleren van een nieuwe rechtvaardigingsgrond die aan de orde komt wanneer een opsporingsambtenaar als verdachte van een commuun geweldsdelict wordt aangemerkt, zoals doodslag of (zware) mishandeling. Een dergelijke methodiek ligt ook ten grondslag aan de aparte strafuitsluitingsgrond in het militair strafrecht (artikel 38, tweede lid, Wetboek van Militair Strafrecht).' Dat artikel luidt: 'Niet strafbaar is de militair die geweld gebruikt in de rechtmatige uitoefening van zijn taak en in overeenstemming met de regels die voor de uitoefening van die taak zijn vastgesteld.' Deze bepaling is kennelijk een specifieke vorm van het wettelijk voorschrift, dat op zichzelf al als een specifieke vorm van noodtoestand kan worden beschouwd. ${ }^{43}$ Deze strafuitsluitingsgrond is dus bedoeld voor de situatie waarin de Ambtsinstructie niet is overtreden. Hoewel niet met zoveel woorden gezegd, lijkt zij vooral van belang voor de fase waarin de officier van justitie moet besluiten al dan niet te vervolgen. Het beantwoorden van die vraag wordt vergemakkelijkt met deze strafuitsluitingsgrond. Wanneer overeenkomstig de Ambtsinstructie is gehandeld, gaat de verdachte politieambtenaar vrijuit en is er dus geen reden hem te vervolgen.

41 Zie art. 76 lid 2 en art. 77 lid 1 sub j Besluit algemene rechtspositie politie.

42 Kamerstukken II 2015/16, 29628, 588, p. 3. Zie ook Blauw 2015, p. 9.

43 Zie De Hullu 2015, p. 341. 


\section{Enkele opmerkingen bij de voorgestelde strafuitsluitingsgrond}

Anders dan het wettelijk voorschrift en de noodtoestand, ontbreekt in artikel 38 lid 2 Wetboek van Militair Strafrecht een verwijzing naar proportionaliteit en subsidiariteit. Dat lijkt mij slechts schijn. Het zinsdeel waarin wordt verwezen naar de regels die voor de uitoefening van die taak zijn vastgesteld, behelzen ook regels van proportionaliteit en subsidiariteit. Dat geldt in ieder geval voor de Ambtsinstructie. Zo bezien lijkt de voorgestelde bepaling geen verruiming in te houden, eerder een verduidelijking. Daar is, gelet op het lex certa-gebod niets mis mee, al is de vraag of de bestaande regeling zo onduidelijk is dat het legaliteitsbeginsel wordt geschonden. Het komt mij voor dat de vraag of aan de Ambtsinstructie is voldaan, in de huidige praktijk een veel moeilijker te beantwoorden vraag is. Dat houdt niet alleen verband met de inhoud van de Ambtsinstructie. Ligt de moeilijkheid niet ook in het handelen van individuele politieambtenaren die de grenzen van de eigen bevoegdheden opzoeken omdat zij of menen dat die grenzen wel wat mogen worden opgerekt, of omdat zij onvoldoende op de hoogte zijn van de precieze inhoud van hun bevoegdheden? De introductie van de bijzondere strafuitsluitingsgrond zou wat mij betreft gepaard mogen gaan met een discussie binnen de politie over de geldende geweldsregels en de bereidheid die regels zonder meer en zonder aarzeling na te leven. Bij de beoordeling van een beroep op deze strafuitsluitingsgrond zou de bereidheid de regels na te willen leven bij de beoordeling van een beroep hierop mogen worden betrokken. Als we deze strafuitsluitingsgrond beschouwen als een bijzondere variant van het wettelijk voorschrift en de noodtoestand, zal binnen de politieorganisatie de bereidheid de eigen normen na te leven voortdurend voorwerp van onderzoek moeten zijn.

\section{Wijzigingen (2): het formele recht}

\section{Politieambtenaar: verdachte en/of getuige?}

Met betrekking tot het formele recht stelt de minister van Veiligheid en Justitie in zijn eerdergenoemde brief: 'Ik ben van mening dat het aanmerken van de opsporingsambtenaar als verdachte na een geweldsaanwending in de uitoefening van zijn functie beperkt zou moeten blijven tot die gevallen waarbij uit feiten of omstandigheden een vermoeden is gerezen dat de betrokken opsporingsambtenaar in strijd heeft gehandeld met zijn geweldsinstructies. Om dat te bepalen moet het mogelijk zijn onderzoek te doen naar de geweldsaanwending zonder dat het hiervoor noodzakelijk is de opsporingsambtenaar als verdachte aan te merken. Als oplossing bezie ik de juridische mogelijkheden om de beoordeling van de geweldsaanwending door het openbaar ministerie zo veel mogelijk met toepassing van onderzoeksbevoegdheden te laten geschieden zonder deze te koppelen aan de status van verdachte voor de opsporingsambtenaar. ${ }^{44}$ Hier zijn enkele opmerkingen op hun plaats.

De keuze om de politieambtenaar in een aantal gevallen aan te merken als verdachte lijkt het resultaat van een compromis tussen aanhangers van de verdach- 
tenstatus en aanhangers van de getuigenstatus. De politieambtenaar is slechts in bepaalde gevallen verdachte, namelijk wanneer het vermoeden bestaat dat hij de eigen geweldsregels heeft overtreden. Waarom de politieambtenaar slechts in dat geval als verdachte kan worden aangemerkt, is nog niet duidelijk gemaakt. De keuze is op het eerste gezicht wel voor de hand liggend. Juist omdat het vermoeden bestaat dat de politieambtenaar zijn boekje te buiten is gegaan, maakt de kans op vervolging (voor overtreding van de Ambtsinstructie) groter. Dan valt te begrijpen dat de politieambtenaar als verdachte wordt aangemerkt. De kans te worden vervolgd lijkt minder groot als de politieambtenaar binnen de grenzen van zijn bevoegdheden lijkt te hebben gehandeld. Zolang het onderzoek wordt verricht conform de eisen die het EHRM aan dergelijk onderzoek stelt, maakt het niet zoveel uit welke status de politieambtenaar gedurende het onderzoek heeft. Het Hof hecht er vooral belang aan dat effectief onderzoek wordt verricht.

\section{Kanttekeningen}

Het citaat maakt ook duidelijk dat nog de nodige vragen moeten worden beantwoord. Wanneer wordt de politieambtenaar als verdachte aangemerkt? Direct na het geweldsincident, na de melding van het incident of op een later moment? De indruk wordt gewekt dat eerst onderzoek wordt gedaan naar de vraag of de politieambtenaar volgens de regels heeft gehandeld. Dat moet kennelijk snel gebeuren, omdat het niet aanvaardbaar is de politieambtenaar lang in onzekerheid te laten. Dat wekt dan wel de indruk dat de vraag of volgens de regels is gehandeld, niet moeilijk valt te beantwoorden. Dat is met de nieuwe Ambtsinstructie wellicht minder moeilijk dan nu, maar het komt mij voor dat op dit punt wellicht wat al te positief wordt gedacht. De vraag of in overeenstemming met de Ambtsinstructie wordt gehandeld, blijkt in de praktijk niet altijd eenvoudig te beantwoorden. Zolang die vraag echter niet is beantwoord, kan niet worden bepaald wat de status van de politieambtenaar is. Dat creëert een vacuüm en dat acht ik onwenselijk. Mij lijkt dat vrij snel ervoor moet worden gekozen welke status de politieambtenaar in het onderzoek heeft. Aan beide statussen (verdachte of getuige) zijn haken en ogen verbonden. De keuze voor een status is volgens mij afhankelijk van de vraag of er op basis van feiten en omstandigheden een redelijk vermoeden van schuld aan enig strafbaar feit bestaat (art. 27 lid 1 Sv). De wet maakt op dit punt geen onderscheid en het lijkt mij dat dit onderscheid niet moet worden gemaakt, omdat dit de structuur van het strafproces (en het Wetboek van Strafvordering) raakt. Hoe wezenlijk het onderwerp voor de politie ook is, afwijken van de uitgangspunten van het wetboek lijkt mij niet aan de orde. Met betrekking tot het onderzoek lijken mij de eisen van het EHRM (dat effectiviteit benadrukt) en de toegang tot een raadsman (ook) voor politieambtenaren van belang. De status (verdachte of getuige) lijkt mij van minder groot belang. Ik begrijp dat dit een wezenlijk punt is voor de politie, dat volgens mij toch vooral op emotionele gronden is gestoeld, maar mij lijkt dat binnen de bestaande uitgangspunten in elk concreet geval zo veel mogelijk naar maatwerk moet worden gezocht, met een goede (gefinancierde) rechtsbijstand.

De minister wil het onderzoek zo veel mogelijk laten geschieden 'zonder deze te koppelen aan de status van verdachte voor de opsporingsambtenaar'. Dat valt te 
billijken zolang er geen redelijk vermoeden van schuld kan worden aangenomen. Daarbij geldt dat dit er niet toe mag leiden dat bepaald onderzoek, noodzakelijk voor het achterhalen van de waarheid, niet wordt uitgevoerd. In dat verband is van belang dat wordt voorkomen dat het onderzoek voornamelijk wordt gericht op het al dan niet naleven van de Ambtsinstructie. Het onderzoek moet primair zijn gericht op het geweldsincident. Of daarbij de Ambtsinstructie is nageleefd, is een van de te beantwoorden vragen.

\section{Slot}

De politie mag bij haar taakuitoefening in bepaalde gevallen gepast geweld gebruiken. Tegelijkertijd zijn haar bevoegdheden niet onbeperkt. Als de politie burgers wat aandoet, hoe gevaarlijk die burgers misschien ook zijn, moet zij aan de samenleving verantwoording afleggen voor (de gevolgen van) haar handelen. Het is begrijpelijk dat om de zoveel tijd wordt nagedacht over de bevoegdheden van de politie, de beoordeling van politiegeweld en de positie van politieambtenaren die geweld hebben aangewend. De voorstellen die nu op tafel liggen, bieden een interessante basis voor discussie. In het vervolgtraject moet een aantal onderwerpen worden geadresseerd: wat is het verschil tussen burgers en politieambtenaren als het gaat om geweldsmisdrijven en zou dat verschil een wijziging in de wettelijke regeling van geweldsmisdrijven kunnen rechtvaardigen, hoe wordt voorkomen dat het onderzoek zich te zeer beperkt tot de vraag of de Ambtsinstructie al dan niet is nageleefd, moet het aangewende geweld onderdeel zijn van de delictsomschrijving schending van de Ambtsinstructie, welke meerwaarde heeft een aparte strafuitsluitingsgrond, en hoe kan in het onderzoek naar aanleiding van het geweldsincident een vacuüm in de rechtspositie van de politieambtenaar worden voorkomen? 